\title{
Financial Obligations in the Implementation of Free Fee Primary and Secondary Schools Education in Arusha District Council - Tanzania.
}

\author{
SOLOMON OLE SABAYA (PhD Candidate) \\ Faculty of Education, Postgraduate Education Mwenge Catholic University Moshi Tanzania East Africa.P. O. \\ Box 1226 Moshi, Tanzania.
}

\begin{abstract}
The government of the United Republic of Tanzania in early 2014 introduced offering primary and secondary schools education without school fees. The main objective of this study was to find out if the government grants to enhance free fee education in public primary and secondary schools in Arusha District Council were used efficiently. The first specific objective was to find out if the head teachers/headmasters draw up budgets for their schools according to priorities of the school needs, the second specific objective was to ensure competency on financial management in public schools; and the third specific objective was to find out if monitoring and controlling of the institutions budget was carried out by head of public schools in collaboration with stakeholders. The findings have shown that the government grants for free fee education were appreciated. It was discovered a shortage of teachers with financial accounting qualifications at the targeted schools which raises a concern to look out how to fill the gap by employing the qualified ones. Short term seminars or workshops were doubted if they could make someone competent in handling school finances. Stakeholders were involved in schools budget preparation and support.
\end{abstract}

Key words: Government grants, free fee education, budgets, monitoring and controlling of the institutions budget. DOI: $10.7176 / \mathrm{JEP} / 11-9-24$

Publication date:March $31^{\text {st }} 2020$

\subsection{INTRODUCTION}

\subsection{Background of the Problem}

The president of the United Republic of Tanzania Dr. John Pombe Joseph Magufuli in his speech addressing the nation about educational difficulties for the majority of Tanzanians, introduced free fee primary and secondary schools education. Parents' complains based on the hardship of payment and other costs facing their children schooling. He pledged that free fee primary education will start from standard one to standard seven, and form one to form four for those who passed the National Primary School Examinations. This became away to release the parents who were complaining of financial scarcity. The Tanzanian children from January 2016 all over the country experienced a smooth way of attending their respective classes without obstacles of being returned homes because of failure to pay school fees.

Tanzania prepared herself to offer free fee education for all children at government's schools emphasizing to the parents and guardians to abide on the rules and regulations. According to the education policy (2014) Tanzania granted capitation grants for running schools by providing the following categories for analysis: Office expenses 35\%, Academic $30 \%$, Mock examinations 15\%, Medical (First aid kit) 10\% and Maintenance 10\%. (M. A. Pawaga 2015, p. 5)

\subsection{Statement of the Problem}

Parents and local communities have been paying school fees in previous years which were a big burden to them. They have being raising money for school development, purchase of text books, school fees and other facilities that led many parents not to be able to send to school some of their children. The government tried all the best to grant a free fee education which led every Tanzanian parent to be eager to send their children to school. The justification show that after the introduction of free fee education policy, students' enrolment pushed up by 21.8 percent as Jacob Mosenda wrote "Teacher - pupil ratio keeps worsening" (Tuesday 21 January 2020, The Citizen Newspaper, p. 4.).The head of schools therefore, found themselves with the responsibilities to make sure that the received money was taken care to avoid misuse of public funds to meet the goal.

This research focused on the problem that faced financial management in schools on planning, budgeting, monitoring and controlling of government grants as a way to implement primary and secondary schools free fee education in Tanzania. The research was to identify in which degree the school financial obligation carried out for the implementation of Free Fee Primary and Secondary Schools Education after the introduction of educational 
capitation grants from the government. It seeks to see if the heads of schools, head teachers, bursars have adequate knowledge and skills on financial management and the way forward to solve the problem.

\subsection{Objectives of the Study}

(i) To find out if head of schools draw up budgets for their schools according to priorities of the school needs with the involvement of the community around such as parents or guardians for the goal of offering free fee education.

(ii) To find out if head of public primary and secondary schools are competent in identifying and mobilizing financial resources such as grants from the government and other income for their institutions to enhance free fee education.

(iii) To find out if monitoring and controlling of the school budget is carried out by the heads of public schools respectively to meet the goal.

\subsection{Research Questions}

This study was guided by the following research questions:

Q1. What are the perceptions of various groups given grants for primary and secondary schools education in Tanzania?

Q2. What causes dissatisfaction among teachers on school funds disbursement?

Q3. What are the qualifications of teachers responsible for the financial management in targeted schools?

Q4. Apart from Tanzania being offering free fee education, what are the parents / guardians role(s) to play?

\subsection{Justification of the Study}

(i) Parents who used to complain about the expenses they were paying for their children's schooling, due to the Tanzania Educational policy (2014) which released the parents from carrying the great burden such as paying school fees; the idea was received positively by the stakeholders.

(ii) School parents committee, school Board of Directors of public schools shared in decision making and helped to improve on a conducive children schooling environment.

(iii) The government improved education sector by sending educational grants on time to public schools to ensure that these schools offer quality services to all Tanzanian children.

(iv) The parents and guardians experienced the school fees released by the government grants to facilitate free fee education for Tanzanian children.

(v) The government continued to conduct in-service seminars for nonefinancial personnel as a way to improve their performance on financial matters at their respective schools. 


\subsection{Conceptual Framework}

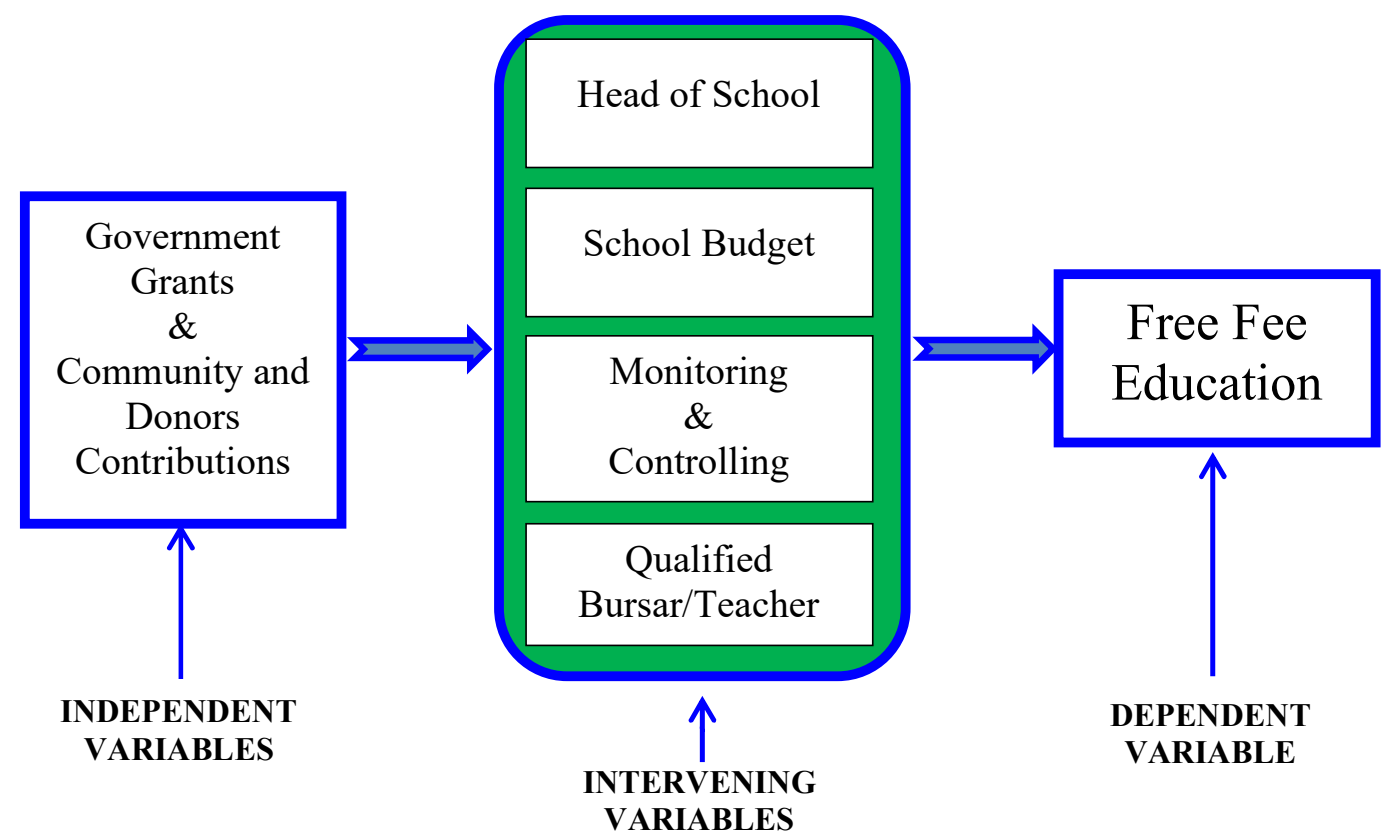

Fig Source: Article’s writer (original 2020)

\subsection{REVIEW OF LITERATUKE}

The participation of parents in the preparation of their children's education is very vital. For example, Paciorek, K. (2012) says, "the extent to which families are involved in their children's education is a strong predictor of children's academic success" (p. 18). He continues that, "The teachers and school take specific steps to enhance parents' capacities to foster their children's readiness and to support children's learning in and outside of school. For example, teachers use an open-door policy that allows for, welcomes, and involves families' participation in classroom activities at all times of the day." (p. 170). Managing towards the achievement of educational aims is vital but these must be purposes agreed by the school and its community (Bush, T., 2008, p. 2)

Financial management in education is concerned with the cost of education, sources of income to meet the educational costs and the spending of the income in an objective manner in order to achieve the educational objectives... education is both consumption and an investment in human capital by individuals and society. Educated people acquire knowledge, skills and attitudes which enable them to receive higher earnings and also to play an active role in societal development (Okumbe, J. A. 1998,p. 196). Leadership and management need to be given equal prominence if schools and colleges are to operate effectively and achieve their objectives (Bush, T. \& Middlewood, D., 2013, p. 5).

"A well planned and executed budget enables educational organization to be managed in an economical manner. Wastage in financial management overestimate the costs of education and this in turn affects the overall provision of educational services. A budget plan should ensure prudent financial management. This in turn enhances efficiency in the provision of educational services" (Okumbe1998, p. 200)

Mbiti, D. M. (2003) writes, "No organization can expect efficiency in its operations without sound planning. By planning is meant a purposeful preparation, in advance of what is to be done in future. Planning is an attempt to get ready for the future today and, therefore, a wise way of avoiding the frustration of having to do things at the last minute. An administrator who plans ahead is likely to get things done efficiently. Plans are estimates of future requirements in terms of money, manpower and equipment" (pp. 10 - 11); he continued that, "The rising cost of education, as of most other things, is a continuous process. This is a challenge to educational administrators to plan the educational budget in such a way that it caters for both existing curriculum requirements as well as newly designed program on trial or on experiment. Funds are always limited. However, educational 
budgets must be prepared in such as way that both the quality and quantity of curriculum requirements are accommodated" (Mbiti, p. 114)

The granted education in Tanzania needs to be efficient and effective to build positive results in schools. Planning and budgeting as the two stages in a cycle of events at an educational institution aimed at enhancing its ability to serve its customers, that is, parents, pupils and the community. Jacob Mosenda writing on "Teacher pupil ratio keeps worsening" asserts that 'The introduction of fee-free education has also made apparent the need of increasing the number of teachers given the population and enrolment pressure",, said Anders Sjoberg, Swedish

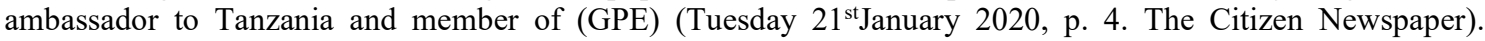
Therefore, the high number of students enrolment need to be considered in the government budget.

The Commonwealth Secretariat \& Ministry of Education, NCERD Guyana (2009) in resource materials for school headteachers writing on "Financial Management"(module 5) says that managing funds is one of the major tasks of a school head. The success of any school programme depends very much on the way the financial inputs are managed and this, in turn affects the overall performance of each school. It is therefore important that all schools heads have a sufficient knowledge of finance to be able to be effective financial managers. However, financial management is one of the areas where many practicing heads have had neither pre-service nor in-service training prior to their appointment and this has contributed to school financial resources not being utilized to maximum benefit (p. 3)

\subsection{Financial Management of Educational Institution}

Financial management is a control system that determines how to use the available resources to produce quality results. It involves defining the goals of the organization, developing programs that will help to achieve the goals of enabling every child to have a chance of getting education in Tanzania. The transformation of any organization / school depends upon the way financial resources are managed. It is thus important that all school heads have an adequate knowledge on financial management and be able to correctly control the institutions' finances. It is essential that headteachers / head masters are well equipped with financial procedures and able to apply well.

\subsection{Planning and Budgeting of School Finances}

Noreen, E., Brewer, P. and Garrison, R (2008) write, “An important part of planning is to identify alternatives and then to select from among the alternative the one that best fits the organization's strategy and objectives (p. 6).Planning is a decision making or way of identifying about what to do to correct the situation and to point out what to be done, when, how, where and by who. Preparing a school budget use steps such as identification of activities need to be completed, identification of resources and resources utilization.

Following budgetary guidelines given by the ministry of education in Tanzania and obtaining / gaining approval of the budget, sources of funds are identified into two major categories namely, the government grant for free fee education, parents and donors willingly contributions just to support the effort made by Tanzanian government in reference to TAMISEMI writ Na. 13 with ref. Na. CAB.110/156/01“B”/11 (Mussa I. Iyombe, 2016, p. 1).The idea is in agreement as Benton (2014) writes "when the cost of materials and subassemblies increased did management attempt to investigate alternative methods to the planning and control of the acquisition and transformation functions in the organization" (p. 4).Sorenson, R. and Goldsmith, L. (2018) say it is the integration of vision within the school budgeting process that transforms school budgeting from merely number crunching to purpose - driven expenditures supporting academic success for all students. An articulated and shared vision creates an environment necessary for planning for academic success for all students to flourish. (p. 4)

\section{(i) Planning}

According to Babyegeya (2002), the planning-programming-budgeting-system (PPBS) is an approach to decision making which is systematically integrate all aspects of planning and program implementation. As a procedure, it involves organization of information, analyzing systematically the consequences of the alternatives selected, before and after implementation of the project (p. 49).

\section{(ii) Budgeting}

The budget is much more than the collection of numbers; it is an important tool for the school for administrators to understand and use in achieving their basic mission-educating children in the most effective and cost-efficient manner (Hartman 2003, p. 2).Managers of schools need to look ahead, establish what comes first and plan the activities in the school. If they do this, they will manage their money well. Clear long term plans and priorities will bring about effective school financial management. The managers should have to be thinkable people avoiding to implement plans that are not planed which will drive the institution into total failure. The development plans should have drive impact on the improvement of education qualities. Macharia (2015) points out that it is 
wrong for schools to strain parents by initiating costly projects like the purchase of buses that had no direct impact on the improvement of education standards (p. 169).

\subsection{Monitoring and Controlling of School's Budget}

For monitoring a school budget, one must be equipped with knowledge on school income and expenditures. The school has various departments and each one located an amount of money according to the budget. The head of school as a school in charge, he/she must make sure that every department must be responsible for the disbursement of the fixed amount in the budget. The head of school must focus on the targeted priorities that has been given the consideration in the budget to makes sure if the amount located was enough or inadequate. The Commonwealth Secretariat \& Ministry of Education, NCERD Guyana (2009) writes "monitoring and supervising the school budget goes on throughout the year. However, at the end of the year, the total amount of income and expenditure is consolidated in a yearly financial account which is drawn up according to a strict procedure....Controlling a school budget requires one to understand the financial state of a school by putting emphasis to priorities for expenditure. Therefore controlling the budget means when doing purchasing you must check what is budgeted so to avoid pay something not in budget or paying less than required" (Ibid., 24).

\subsection{METHODOLOGY \\ 3.1 Study Population}

The targeted population for this study was made up of heads of public schools, teachers, parents or guardians.

\subsection{Sample Population}

Ten public primary schools and ten public secondary schools in Arusha District Council purposefully selected for the study to meet the objectives. The study area studied was purposively selected after the investigation by checking with the government decision of offering free fee education to all children in Tanzania by visiting schools and the consultation of the current educational policy documents.

\subsection{Research Instrument}

The questionnaires items were used as research instrument to obtain information. Four different questionnaires were prepared to collect data from heads of schools, teachers and parents or guardians who were directly associated to the management and stakeholders of the public primary and secondary schools in Arusha council. They contained items composed of opened and closed ended questions.

\subsection{FINDINGS AND DISCUSSION}

Parents or guardians of both primary and secondary schools children were asked to see if they appreciate services given by the government on the area of primary and secondary schools education. Returned ten (10) questionnaires out of ten which were distributed to primary schools parents and guardians acknowledged to appreciate the services offered by the government at primary school level which made a $100 \%$ percent of acknowledgement; where at secondary school level out of ten (10) distributed questionnaires to parents and guardians, 7 parents which make $70 \%$ percent acknowledged to have appreciated services granted by the government for secondary school education in Tanzania; 3 parents or guardians out of ten (10) which make $30 \%$ percent didn't acknowledged. From the findings above the government services towards free fee education was appreciated to the reasonable capacity.

To ensure cooperation between school management and parents or guardians the question was asked to see if reports of income and expenditure were read before parents meetings: The findings show that eight (8) respondents out of ten(10) which make $80 \%$ percent at primary school level agreed that reports of income and expenditure were read during parents meetings one (1) respondent from primary school level which make $10 \%$ percent disagreed that income and expenditure report to have been read before parents meetings. One (1) respondent of which makes $10 \%$ percent of the respondents was not sure of the asked question. At the level of secondary schools five (5) respondents out ten (10) which make 50\% acknowledged that reports of income and expenditure were read before parents meeting while five (5) respondents disagreed which make 50\% percent. From the above findings at primary school level, one respondent who disagreed and who was not sure of the report to be read found himself not good in attending school meetings. From secondary school level the respondents divided into two halves that 50\% percent acknowledged and 50\% percent disagreed and this need more improvement in the involvement of school reports to be read before the stakeholders regularly. 
The researcher looked out to see if the parents were represented in the primary and secondary schools budget preparation. At primary school level nine (9) respondents out of ten (10) which make $90 \%$ percent accepted that parents were represented in the school planning budget one (1) respondent which makes ten $10 \%$ percent didn't agree that parents were represented. At the secondary school level six (6) respondents out of ten (10) which make $60 \%$ percent agreed that parents or guardians were represented in the school planning and budget preparation. Two (2) respondents which make $20 \%$ percent disagreed while two (2) which make $20 \%$ percent were not sure if parents were represented. From the observation at the primary school level a higher percent of parents accepted to have been represented in the school planning and budget preparation through school committee members. However, at the secondary school level six (6) respondents which make $60 \%$ percent agreed that parents are represented which is likely a reasonable percentage.

The researcher went beyond to see if the government grants for free fee education acknowledged to be benefiting the students. At primary school level all ten (10) respondents which make $100 \%$ percent acknowledged that the government grants for free fee education benefits the students. At the secondary school level five (5) respondents out of ten (10) which make 50\% percent acknowledge that the government grants for free fee education benefit the students; while five (5) respondents that make $50 \%$ percent were not sure if the government grants benefit the students. At the primary school level above parents acknowledged to be benefitting the grants from the government to enhance free fee education. However, at the secondary school level the respondents divided into two halves whereby 50\% percent acknowledged the grants to be beneficial and 50\% percent were not sure if the grants benefit the students.

The researcher intuited to see the awareness of parents on government grants for free fee education and the roles played by parents willingly. At primary school level all ten (10) respondents out of ten (10) which make $100 \%$ percent agreed that they have information about the government grants on free fee education to be having responsibilities to play as a way to enhance education for their children in Tanzania. At the secondary school levels, eight (8) respondents out of ten (10) which make $80 \%$ percent agreed that they are aware of the grant from the government and they have admitted to be having the responsibilities to play for their pupils /students education. Two (2) respondents which is $20 \%$ percent disagreed. At both primary and secondary schools, the respondents agreed to be having information on grants for free fee education and the roles parents to play willingly. This is justified by a $100 \%$ percent for primary school and $80 \%$ percent for secondary school.

The researcher looked forward for the clarification of awareness of parents on the policy 2014 to enhance free fee education. At both primary and secondary schools level all ten (10) respondents out of ten (10) which make $100 \%$ percents agreed that they have responsibilities to play and also to abide on the 2014, policy which insists free fee education. As the policy 2014 insists on free fee education (Policy 2014: 3.1.5 p. 24).

The researcher asked the parents to mention some of the responsibilities to play for their children schooling apart from the government grants. Nine (9) respondents out of ten (10) which make $90 \%$ percent acknowledged to be having responsibilities to play apart from the grants given by the government. They were able to justify by mentioning things like school uniforms, food, transport, stationary and medication. One (1) respondent who makes $10 \%$ percent was not sure of the above question. At the secondary school level all ten (10) respondents which make $100 \%$ percent agreed to have responsibilities to play apart from the grants from the government; they were able to mention different necessary educational facilities to contribute to enhance their children education e.g. school uniforms, food, medication, books, and transport.

The researcher wanted to see if parents are aware of the big population of primary school pupils joining secondary education and the need of helping them to have adequate class rooms. At primary level ten (10) respondents out of ten (10) which make $100 \%$ percent agreed that there is a big number of primary school pupils joining secondary school educational; they acknowledged to have roles to play willingly to contribute to build classrooms and other educational infrastructures. At the secondary school level all ten (10) respondents out of ten (10) which make $100 \%$ percent agreed to have responsibilities to play as a way to boost up their children education at secondary school. They were able to acknowledge to be able to build classrooms, laboratories, dormitories and toilets.

The researcher hoped to know if the head teachers or headmasters had adequate knowledge on financial management. At primary school level, all ten (10) respondents which make $100 \%$ percent agreed to have adequate knowledge on financial management; however the knowledge is obtained through various seminars and workshops. At secondary school level nine (9) respondents out of ten (10) which make 90\% percent agreed that the head of schools have knowledge on financial management at their schools. The said knowledge was obtained 
through various workshops \& seminars. Many of seminars or workshops were prepared by the Agents for the Development of Educational Management (ADEM) www.adem.ac.tz

According to the findings mentioned by the head teachers and heads of secondary schools knowledge obtained on financial management to the big extent given to the teachers of different fields (subjects) rather than financial field. The respondents mentioned the said qualifications to have been obtained through various seminars and workshops. The writer of this article was in doubt if a short term seminar or workshop between two and five days can make a certificate offered for attendance to qualify that individual.

The study intended to know the number of the head teachers and headmasters with the knowledge of financial management in each visited school. All ten (10) respondents out of ten (10) from primary school which make $100 \%$ percent agreed that in their respective schools there was at least two (2) teachers with basic knowledge of financial management. At secondary school level, five respondents out of ten (10) which make $50 \%$ percent agreed that apart from the head of school others teachers have a basic knowledge on financial management. Three (3) respondents out of ten (10) which make 30\% percent said that there are no any teachers with financial management knowledge apart from the headmaster. Two (2) respondents which make $20 \%$ percent out of ten (10) were not aware of what was going on.

The researcher wished to see if the departments were represented in the planning and preparation of the school budgets. At the primary school level, all ten (10) respondents which make $100 \%$ percent agreed that department's requirements presented in the school budget preparation. At secondary school level all ten (10) respondents which make $100 \%$ percent agreed that departmental requirements were presented during the preparation of the school budget. Some said they presented the list of the requirements and other said they were invited in a school management meeting to express the needs of their departments.

The researcher investigated to see the qualifications of the teachers with financial management knowledge and skills. At primary school level eight (8) respondents out of ten(10) acknowledged that at least in primary school one teacher has a certificate of accounting from teachers training college or workshops and seminars attendance. At secondary school level four(4) respondents out of ten (10) which make $40 \%$ agreed that there are teachers with financial management qualifications at their respective schools ranking as follows: Three (3) Certificates, Two (2) Diploma and(2)Certified Public Accountant (CPA).

The researcher pointed out to know if the head teachers or headmasters have a habit of calling teachers meeting to discuss school money disbursements. All ten (10) respondents (head teachers out of ten (10) which make $100 \%$ percent at primary school level agreed that they have a habit of calling teachers meeting to discuss financial reports. Often they meet once a month after receiving the free fee educational grants from the government and locate to the respective departments according to the budget. At the secondary school level nine (9) respondents (headmasters or headmistress) which make $90 \%$ percent agreed that they call teachers meetings to discuss school funds. One respondent did not understand what the question demanded.

The researcher went far to seek from the head teachers and headmasters if they have teachers at their schools with qualifications in financial accounting. At the primary school level, nine (9) female teachers reported to be having basic qualification on accounting; Two (2) schools found to be having more than one female teacher with qualification of accounting. Out of ten (10) respondents four (4) male teachers found to be having basic qualifications on accounting. At the secondary school level, six (6) respondents out of ten (10) reported to be having six male teachers with the basic knowledge of accounting; One female teacher is reported to be having basic qualifications on accounting. At the secondary school level above, two (2) schools seem to be not having teachers with financial accounting qualifications. This raised a concern that there is a need to make sure the qualified personnel to be placed to such schools.

The researcher indented to see if the head of school or headmasters have plan to invite a qualified and experienced accountant to conduct seminars on financial management. At the primary school level, six (6) respondents, out of ten (10) which make $60 \%$ disagree to be having a plan of inviting qualified account to offer seminar on financial management at their respective schools, instead they acknowledged to have attended seminars conducted by district council. Two (2) respondents out of ten (10) which make $20 \%$ percent agreed to be inviting qualified and experienced accountant; however ended up referring seminar's conducted by the district level council to have been participated. Two (2) respondents out of ten (10) which make $20 \%$ percent disagreed to be having a plan of inviting qualified accountant to conduct financial management seminars at their schools. At the secondary school level, five(5) respondents out of ten (10) which make $50 \%$ seem to be in a dilemma; that some acknowledged to be inviting persons with qualifications to conduct seminar at their schools but at the same time 
revealed to have attended seminars/workshops at district council level. Where at secondary school level $50 \%$ percent of the respondents disagreed and another 50\% percent remained in a dilemma ending up referring to be attending seminars conducted by the district council.

The writer of this article prepared a percentage scale of the levels of need ranking between $20 \%$ percent $40 \%$ percent, $60 \%$ percent and $80 \%$ percent to see in which percentage the respondents interested in support from educational donors rather than the government grants to enhance education. At the primary school level 5 respondents out of ten (10) which make $50 \%$ percent show to be interested with donors support in $80 \%$ percent. Three (3) respondents show to be interested in donors support by $60 \%$ percent and at least two (2) respondents show to be interested in donors support by $40 \%$ percent. This is to say educational expert in primary school level are interested to invite different support for education activities at their schools. The secondary school level, three (3) respondents out of ten (10) show to have interested to get $80 \%$ percent grant from the donors. Two (2) respondents out of ten show the interested to be assisted by $40 \%$ percent. Two (2) respondents show to be interested to get $60 \%$ percent from donors; Two (2) respondents didn't show if they need donors supports and one (1) respondent out of ten (10) shown interest to be supported by $20 \%$ percent.

\subsection{CONCLUSIONS AND RECOMMENDATIONS 5.1 Conclusion:}

Free fee education in both primary and secondary schools in Tanzania is a very unique trend. As it was pledged by the president of the United Republic of Tanzania things came into practice for children who passed their National Primary School Examinations. So many parents who were complaining about the concerned pertaining hardship of payment fees and other costs facing their children's schooling got an answer. The Tanzanian children from January 2016started to experience a friendly way of attending their classes without obstacles. Free fee education for all was possible in public schools emphasizing to the parents and guardians to abide to the rules and regulations.

Education in Tanzania as a growing industry, consumes a large amount of the government budget. Besides the grants from the government for free fee education efforts the cost sharing has left some responsibilities to the parents and guardians such as school uniforms, stationeries, medications, transport and food for students while at schools.

To ensure good governance of financial facilities at the public schools, qualified experts on the area of finance need consideration. This will make possible for the monitoring and controlling of educational institutions financial resources management.

\subsection{Recommendations:}

Considering the findings and conclusions of this study, the following recommendations were made:

(i) The Ministry of Education Science and Technology to review the curriculum for the business studies subjects to move with the need of current situation that schools receive the money from government, donors, stakeholders and therefore the money need qualified people for handing by mastering financial management norms. Thus will make possible to employ qualified bursar for full time and teachers to do the same work partly.

(ii) Head of schools should find other ways of solving small financial problems together with parents and the government as far as funding is concerned both educational facilities.

(iii) Heads of schools should involve other stakeholders in the school activities in budget building to provide cost effective educational programs that meet student's needs.

(iv) The school administrators should be accountable to the government as far as expenditure within the budget is concerned and should show a high degree of transparency and accountability.

(v) It is advisable that the entire school community to be involved in the monitoring and controlling of the school budget.

(vi) The school Board of Directors and school committees should seek the proper format of priorities for the government to approve and assuring of what is needed in every school budget. .

Acknowledgements: The writer acknowledges the Meru District Executive Director, Meru District Council Educational Officer and Meru Human Resource Manager for allowing him to join Mwenge Catholic University to 
pursue his studies. He won't forget the following people who for one way or another did put their effort to make this work to its success: Rev. Lazaro P. Leyan who provided library services; my wife Kesiah and children Stanley, Lightness, Nanyori, Olarip, Esupat, Witness and Jesca for their tolerance during all the time of writing this article.

\section{REFERENCES}

Babyegeya, E. (2002). Educational planning and administration. Dar es salaam: The Open University ofTanzania.

Benton, W. C. (2014). Purchasing and supply chain management. New York: McGraw Hill.

Bush, T. (2008). Leadership and management development in Education. London: SAGE Publications Ltd.

Bush, T. \& Middlewood, D. (2013).Leading and managing people in education. London: SAGE Publications Ltd.

Commonwealth Secretariat \& Ministry of Education (2009).NCERD Guyana.

Hartman, W. (2003). School district budgeting. Oxford, UK: Association of School Business Officials International.

Iyombe, Mussa I. (2016). TAMISEMI government writ Na.13 with ref. Na. CAB.110/156/01 “B”/11.

Jamhuri ya Muungano wa Tanzania (2014). Wizara ya elimu na mafunzo ya ufundi: Sera yaelimu na mafunzo. Dar es salaam.

Macharia, C. (2015). International Journal of Scientific and Technology Research. Vol. 4, Issue09, September.

Mbiti, David M. (2003). Foundations of school administration. Nairobi: Oxford University Press.

Mosenda, Jacob. (Tuesday 21 January 2020). Teacher - pupil ration keeps worsening. The Citizen.

Noreen, E. W., Brewer, P. C.\& Garrison, R. H. (2008).Managerial accounting for managers.New York: McGrawHill.

Okumbe, J. A. (1998). Educational management: theory and practice. Nairobi: NairobiUniversity Press.

Paciorek, K. (2012), ed. Early childhood education. New York: McGraw Hill.

Pawaga, M. A. (2015). Capitation grants. TAMISEMI, Dodoma.

Sorenson, R. \& Goldsmith, L. (2018). The principal's guide to school budgeting. London:Gorwin, a SAGEPublishing Company.

$\underline{\text { www.adem.ac.tz }}$ 